\title{
Using a digital scientific communication genre to improve students' oral skills
}

Un genre numérique de la communication scientifique pour améliorer l'expression orale des étudiants

\section{Susan Birch-Becaas}

\section{(2) OpenEdition}

\section{Journals}

Electronic version

URL: https://journals.openedition.org/asp/7422

DOI: $10.4000 /$ asp.7422

ISSN: 2108-6354

Publisher

Groupe d'étude et de recherche en anglais de spécialité

\section{Printed version}

Date of publication: 1 November 2021

Number of pages: $21-36$

ISSN: $1246-8185$

\section{Electronic reference}

Susan Birch-Becaas, "Using a digital scientific communication genre to improve students' oral skills", ASp [Online], 80 | 2021, Online since 01 November 2021, connection on 05 December 2022. URL: http://journals.openedition.org/asp/7422 ; DOI: https://doi.org/10.4000/asp.7422

This text was automatically generated on 5 December 2022

All rights reserved 


\section{Using a digital scientific communication genre to improve students' oral skills}

Un genre numérique de la communication scientifique pour améliorer l'expression orale des étudiants

\section{Susan Birch-Becaas}

\section{Foreword}

Marie-Hélène Fries, Université Grenoble-Alpes

2 Could the notion of multimodal literacy inspire teaching in the context of English for specific purposes (ESP)? In science and technology at least, multimodality plays an essential role, as noted by Sionis in this journal, when commenting on presentation design for a scientific conference on mechanical engineering:

Their verbal discourse was created and organised to develop and comment on nonverbal materials and not the other way round. Non-verbal materials were definitely not used to 'illustrate' a predominantly verbal type of communication; they were the very subject and the main mode of communication (Sionis 1997: 340).

3 This can be explained by the fact that researchers' work in these domains is mostly based on experiments or on models, both requiring to be expressed in graphs or images as well as in words. On the other hand, the development of the World Wide Web and multimedia technologies have given a crucial importance to images and screens, which now makes it almost impossible to think about literacy in linguistic terms only, as already pointed out by Kress at the beginning of the age of the Internet:

It is no longer possible to think about literacy in isolation from a vast array of social, technological and economic factors. Two distinct yet related factors deserve to be particularly highlighted. These are, on the one hand, the broad move from the now century-long dominance of writing to the new dominance of the image and, on the other hand, the move from the dominance of the medium of the book to the dominance of the medium of the screen. (Kress 2003:1) 
This change has spurred the emergence of a research trend in academic literacies over the last twenty years (Dressen-Hammouda 2021: 81). In this broad context, Susan BirchBecaas has managed to answer the question of the usefulness of multimodal literacy for ESP teaching in a very concrete way. She and her colleague, Laüra Hoskins, have designed an optional course for first year Master students in public health, in which the traditional slide-based, oral presentation is replaced with an animated video abstract, an emerging digital genre reaching a wider audience than domain specialists. The task given to the students involves writing an introduction, producing a short video including "home-made" visuals (paper slides, white board sketches, animations, etc.), reporting critically on a published research article, and presenting it in front of their peers, in a question and answer session. The jury is composed of an English teacher and a domain specialist. Highlighting the role of experts in ESP goes back to Selinker (1979), who advocated consulting "subject-matter specialists" in order to better understand scientific discourse. In the particular case of animated video abstracts, the public health lecturer assesses content and spots potentially inconsistent or misleading points, which enables the English teacher to focus more on communication strategies and linguistic accuracy.

5 This course demonstrates the pedagogical usefulness of multimodal literacy, in both professional and pragmatic terms. As the students seek to become efficient science communicators in an international context, producing an animated video abstract makes them familiar with a real-life task which will be useful to them in their professional lives and help them project more confidently into the future. In order to carry out their tasks, the students also need to turn the written register of a research article into an oral performance, while moving from specialized circles to a wider communication target. This is an excellent exercise in mediation, which also helps them to understand better how meaning is created in each genre (see Kress [2010] for a theoretical discussion), as well as which words, phrases and grammatical structures are more common for public speaking than in writing. In their evaluation of the course, most students confirmed this, as they felt they had improved their grammatical and lexical knowledge and gained a better grasp of the differences between the written and the oral registers of English.

6 Animated video abstracts thus seem to be a promising new Internet genre, not only for science communicators, but also for ESP practitioners. They have certainly proved to be a creative response to the constraints of oral presentations on Zoom in times of pandemic, but their interest reaches far beyond this particular situation. The author's concrete and detailed description of animated video abstracts as a pedagogical task is a source of inspiration for ESP teaching in general.

DRESSEN-HAMMOUDA, Dacia. 2021. Methods for developing literacy in professional and academic contexts: Using protocol-assisted modelling. In L.M MURESAN \& C. ORNAMONTESINOS (eds.), Academic Literacy Development: Perspectives on Multilingual Scholars' Approaches to Writing. Palgrave Macmillan, 81-100.

KRESS, Gunther. 2003. Literacy in the New Media Age. Routledge.

KRESS, Gunther. 2010. Multimodality: A Social Semiotic Approach to Contemporary Communication. Routledge.

SELINKER, Larry. 1979. On the use of informants in discourse analysis and Language for Specialized Purposes. IRAL 17 189-215. 
SIONIS, Claude. 1997. The integration of verbal and non-verbal materials in some instances of written scientific discourse. ASp 15-18, 339-355. DOI: 10.4000/asp.3191

\section{The context}

7 At the Département Langues et Cultures, University of Bordeaux, teachers design and implement English for specific purposes (ESP) and professional and scientific communication courses for students in the human sciences and the health sciences. Students beginning a Master 1 "Santé publique" (Master's degree in Public Health) at the Institut de Santé Publique, d'Épidemiologie et de Développement (ISPED) or Bordeaux School of Public Health have obligatory English classes (30 hours) in their first semester which are part of a course entitled "Fundamentals of Public Health", the ability to communicate effectively in an English as a lingua franca (ELF) context being fundamental for these students. There is a cohort of 60 students, divided into three classes with language levels ranging between A2 and $\mathrm{C} 1$. The profile of the students is very varied, some having completed an undergraduate degree in social sciences, biological sciences, statistics and some being health-care professionals returning to their studies. In the second semester, the students can choose to take an optional course in oral and written scientific communication. This optional course is normally taken by approximately 20 students planning to continue in the second year of their Master's degree in the field of international public health or epidemiology. It is a content and language integrated learning course with classes given both by an ESP lecturer (17 hours) and a public health lecturer (nine hours), with the students also completing a personalised pathway in our language centre, the Espace Langues, where they are free to choose their own activities depending on their needs and level (oral workshops, writing lab, oral coaching, tutoring, or online exercises).

8 In this report, I will describe the teaching and learning outcomes and activities of this optional course with a specific focus on the video abstract task which was used to enable students to experiment with an emerging digital scientific genre. The task was expected to motivate them to improve their oral skills as they were working in small groups to create an end-product which would be viewed by the class and could potentially be disseminated. While acquiring digital literacy skills, students had the opportunity to improve on their oral communication by practising, filming and reshooting. I was therefore interested in comparing this task-based pedagogy to that of classic, academic slide presentation.

\section{Course objectives}

The objectives of the course were set by the two lecturers. From a public health perspective, the lecturer wanted students to be able to select, report on and evaluate robust randomized control trials (RCTs) which are used to assess the impact of interventions in the field of public health. From a language perspective, the aim was to raise awareness of the importance of communication for public health specialists and to get students to collaborate on a variety of outputs. As Carter-Thomas and Jolivet have pointed out "today's graduate students need to be able to master and navigate their way through a number of very different genre repertoires" (Carter-Thomas \& Rowley-Jolivet 2020: 1). Hafner and Pun have also emphasised how "the ubiquity of 
digitally-mediated communication gives rise to emerging needs for language learners" (Hafner \& Pun 2020: 3).

10 The intended teaching and learning outcomes were thus that the students would be able to report on a research intervention, for example a programme aiming to optimise treatment for malnutrition, both in the form of a written introduction, an animated video abstract and that they would then be able to defend and extrapolate on their work in a question and answer session. This session was the opportunity for students to showcase their work, ask questions to their peers and give feedback to each group on their video production.

11 Digital literacy practices are thus introduced alongside traditional literacy practices with the aim being "to balance emerging literacy needs with fundamental language needs" (Hafner \& Pun: 6). The aim of the written assignment is for students to introduce the research by explaining the context of the studies, highlighting the importance of the problem from a public health perspective. They then introduce the research question which justified the interventions and briefly present the studies chosen (objective, hypothesis at outset, setting, type of study, etc.). In the animated video, the students go further and describe what the research teams did, what they found and what this means by combining narration with written, visual and video modes. The aim, as we will see below, is to engage their audience using story-telling techniques, oral communication strategies and digital media to effectively communicate public health research. Work on digital literacy has been described in the ESP literature. Hafner and Miller (2011) described a collaborative student digital video project and Perez Llantada (2016) has suggested getting students to create their own audioslides, embedded videos and podcast interviews. Dressen-Hammouda (forthcoming) has recently worked on the production of instructional videos by students in applied languages (Langues étrangères appliquées).

12 I will describe the pedagogical approach of this course, outlining the different activities used to increase awareness of different genres and modes which enable the students to recontextualise the research. I will then examine more closely the animated video task, describing what it involves and how students prepare for it to see in what ways it contributed to enhancing the students' oral skills, especially when compared to the preparation of a more classic oral academic presentation. Student feedback on the course and this task in particular will give an insight into student perceptions of its pertinence and impact on their oral communication skills.

\section{Learning activities}

\subsection{Organisation}

13 The role of the public health lecturer consisted in describing the rationale behind the interventions in his research field. He validated the subjects chosen by the students and the articles they were to focus on. He was also able to question the students more closely on the methodology and findings of the studies during the final question and answer session. The ESP teacher's role consisted in finding and preparing materials, resources which were made available on the Moodle platform (figure 1) and designing interactive tasks to highlight rhetorical and linguistic features in genres such as research articles and video abstracts. Firstly, written, audio and video documents on 
the research topic (malnutrition) to be developed by the public health colleague familiarised students with both content, language and key terms to facilitate their comprehension in an English-Medium Instruction (EMI) context (Marcaro 2018). Course materials and classes also focused on English for research writing (rhetorical strategies, language clusters, encouraging students to notice the use of tenses, citation practices, the author's presence and hedging strategies in their own corpus). This was followed by a move to situated practice and collaborative drafting, editing and revising of their writing. We then examined the move from written to oral discourse with an analysis of example videos. As Carter-Thomas and Rowley-Jolivet have shown,

non-native speakers seem to differentiate less between written and oral modes of scientific communication, tending to overuse, in oral presentations, structures that are typical of writing such as the passive, and not to use structures that are typical of speech such as pseudo-clefts and inversion (Carter-Thomas and Rowley-Jolivet 2001: 17).

Figure 1 Screen capture of the course moodle page.

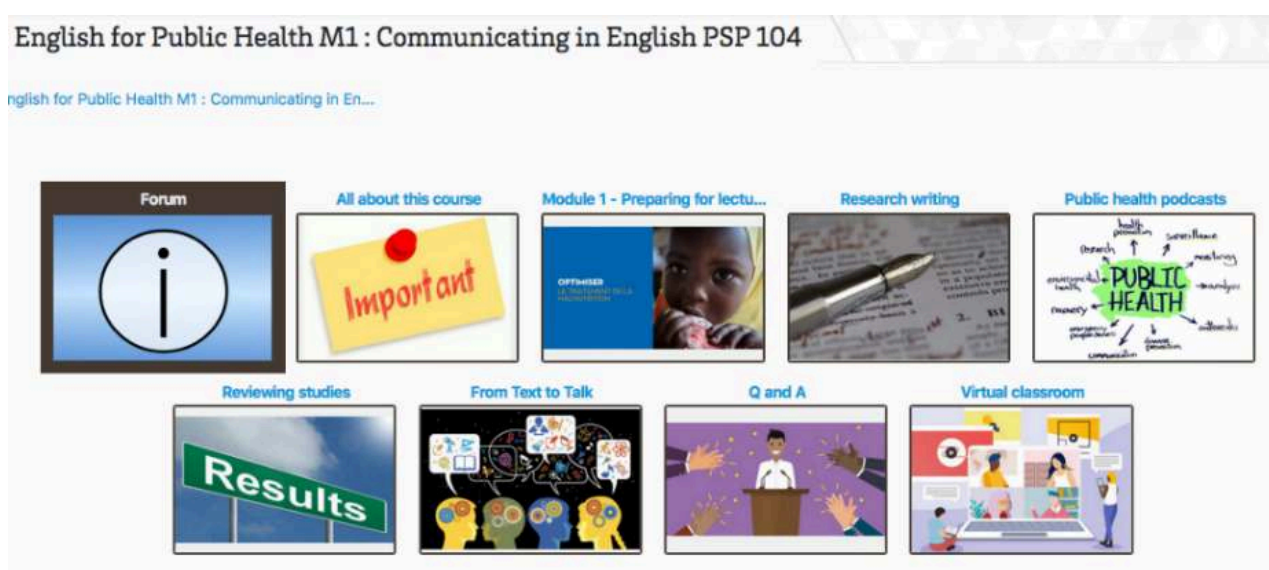

\subsection{Effective communication}

Due to the Covid-19 pandemic which occurred in the academic year 2020-21, the course was run almost exclusively online. This led us to establish a community within the group. After a "getting to know you/information sharing" activity on Zoom, students watched a video interview with a student from the Liverpool School of Tropical Medicine in which she explained why she chose to study international public health, her career goal, the domain she was most interested in, her experience at the school, what she hoped to change with the impact of her research. After the first class, the students were thus invited to record a 1-min Flipgrid video in which they could introduce themselves and share similar information with the other students.

In the first session, students were also encouraged to reflect on the role of communication in science which, as Scientific American reminds us, "is part of a scientist's everyday life. Scientists must give talks, write papers and proposals, communicate with a variety of audiences, and educate others" (Feliu-Mojer 2015). The students then discussed some of the tenets of effective communication summarised by the popular science magazine as "transmitting your message clearly and concisely so 
that it is understood", "engaging your audience", and the fact that communicating across disciplines "fosters collaboration and innovation".

In the context of the Covid-19 pandemic, the importance of the sharing of data, maintaining public trust and adherence to measures has also been underlined as "a key component of an effective pandemic response is communication between governments, health professionals, scientists, the media, and the public" (Wang et al. 2020: 503).

\subsection{Research writing}

17 Research writing consisted in drafting an introduction acceptable to the research community. The approach to research writing was based on genre analysis (Swales 1990) and situated practice (Lave \& Wenger 1991). Learners analysed examples of abstracts, research articles and introductions from the field of study to identify recurrent moves and language clusters. The approach was therefore descriptive rather than prescriptive with Swales' CARS (Creating a Research Space) model being presented after their analysis as one possible structural organisation of an introduction. As mentioned above, the students mined their examples for verb forms, the logical development of ideas, hedging devices to modulate the discourse, authorial presence, citation conventions, tentative explanations for results and indication of limitations. As they were asked to write an introduction, we looked at how to justify the importance of their chosen research subject, how to present current knowledge in the field and how to indicate a gap within the literature or, in other words, the justification for the trial/ intervention in question. Students could then begin to work on their first drafts which were submitted, revised and completed.

\subsection{Oral communication}

After spending time on written scientific discourse, the aim of the course was then for students to demonstrate how they could adapt the discourse to report on the study in the form of an animated video abstract. Such videos are an emerging genre in research communication and can be used to summarise a study and reach a wider audience. Digital story-telling techniques can be used to enhance the communication by, for example, giving the author's critical view of the studies, answering a specific question, giving just enough context to tell the story without information overload and pacing the progression of the story (Robin 2008). The visuals can take different forms such as paper-slide videos, white-board sketches, cartoon animations, talking heads or presentations with a voiceover as can be seen in some tutorials (see "animate your science" ${ }^{1}$ ).

A set of paper-slide videos ${ }^{2}$ had already been produced by Laüra Hoskins, a departmental colleague, as teaching aids to focus on certain grammatical and phonological aspects of English in her online ESP courses. Her simple video guide talks students through the different stages of producing a video ${ }^{3}$ : working on the script, preparing the visuals, getting feedback and practising and then filming and re-shooting if necessary.

20 The task was first used with Master's students in biology at the DLC and it has since disseminated and been adopted by several colleagues with students of medicine, pharmacy and speech therapy amongst others. The main points of a study can thus be 
presented in a more engaging way and they may attract a less specialised audience. This simple pedagogical practice using just smartphones is also described as part of the Erasmus+ project Sharing Open Education Practices Using Technology for Higher Education (SHOUT4HE) ${ }^{4}$. Each scientific journal has its own advice to authors about information to be included in this type of video. For example, Cell Press ${ }^{5}$ recommends a 5 -minute video which gives the main interest and take-home message of the research. In my context though, the students were not presenting their own research but critically reporting on the studies of other researchers.

21 The suggested format, discussed and agreed upon with the public health researcher, thus contained all the typical moves of an abstract (background, objective, methods, results and discussion). The students could therefore, for example, introduce themselves and their research topic, identify the research question and justification for the studies chosen and then go on to give a critical account of the methodology of the studies, present the findings including any potential limitations or applications and conclude with a take-home message. An example video was analysed to identify which moves were present and how they were expressed, enabling students to notice the use and synchronicity of the verbal and visual channel. The videos were thus composed of rhetorical moves close to the research article which were presented in a conversational, engaging style to attract a wider audience.

22 The students mostly used animations but simple paper-slide videos (see figure 2) were also found to be very effective. A podcast-style interview format between a "Lancet journalist" and a researcher was also used. 
Figure 2. Two examples of types of videos produced.

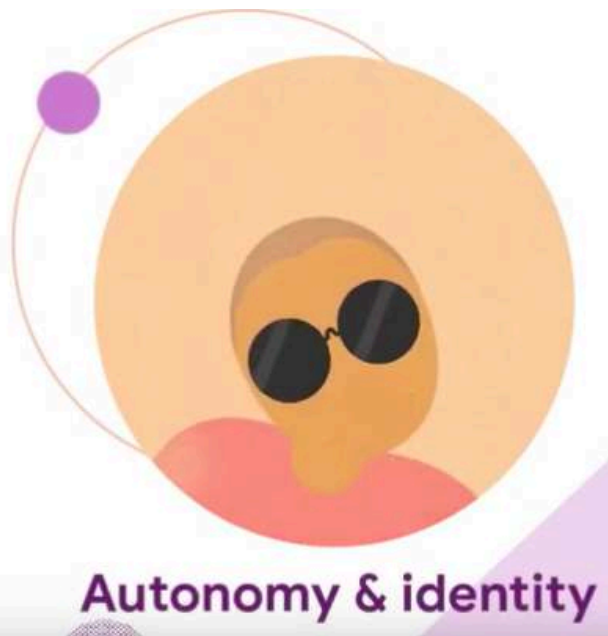

\section{Academic demands}

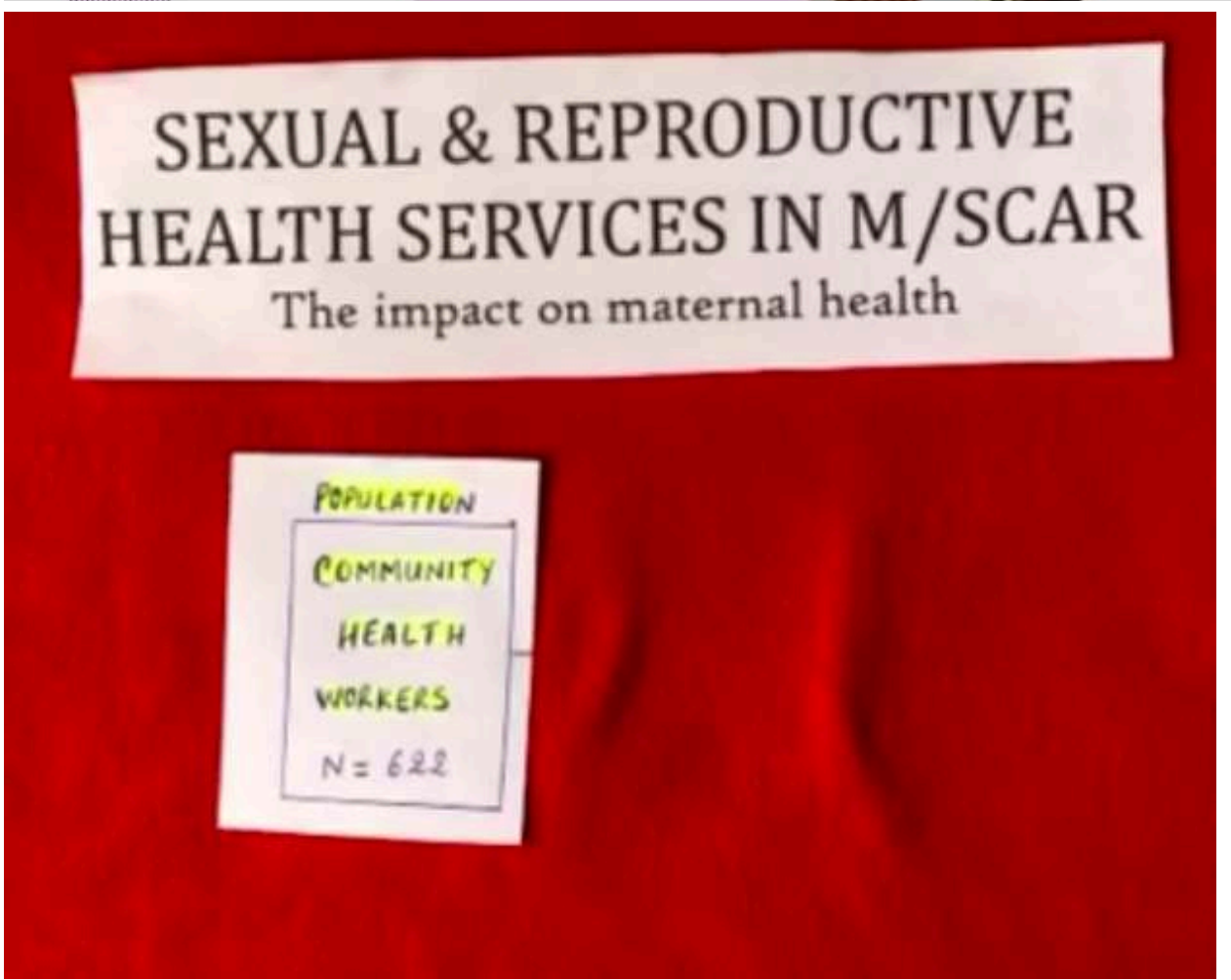

The next step was to look at oral communication strategies and appropriate language elements to announce moves such as the use of rhetorical questions and signposting expressions to signal and make transitions between sections. Attention was drawn to pseudo-cleft structures which have been shown to slow down the discourse flow, chunk the information and help the listener to process it, "enabling the speaker to set the stage for the new forthcoming information, thus increasing its salience" (CarterThomas \& Rowley-Jolivet 2001: 14).

The groups of two to three students could then begin by preparing their script. The preparation of a script enabled students to focus on grammatical and lexical accuracy and extend their grammatical and lexical repertoire in the discipline. The use of a multimodal approach was therefore not found to lessen attention to language, a concern that was recently raised in the literature (Hafner \& Pun 2020). The second step 
was to prepare the visuals (drawings, printed pictograms or animations). The integration of visuals enhances and reinforces the communication making it concise, clear and effective and leads the students to interact with both the visuals and the viewer making for more engaging communication. As we will see below, students used various types of visual images which fall into the categories defined by Rowley-Jolivet (2002), namely graphical (graphs, diagrams and maps), figurative (photos and cartoons), scriptural (text) and numerical (tables and figures). The visuals also encourage students to pace their talk and sequence with signpost expressions to make clearer transitions for the viewer. The fact that the students could practise their script several times enabled them to work on phonological aspects, improving individual sounds, syllable stress, word stress, prosody and also grammatical errors. They were given feedback by the teacher and their peers and therefore had more opportunity to improve. The fact that their videos were going to be showcased to the class, could be disseminated if they wished and viewed several times may have led students to work harder on their oral communication skills and perfect their productions. Students thus tended to attempt a more varied and meaningful intonation, highlighting certain elements of their talk. After these preparatory phases, it was then time to film and, if necessary, re-shoot.

\section{Analysis of the videos}

A brief analysis of the videos will enable us to see the moves used by the students, their selection of the spoken and visual modes and the various interactions with the viewer.

Most groups chose to begin by introducing themselves and their subject underlining its importance as a major public health problem. Figures and maps showing prevalence, for example, were used to reinforce their claims. They clearly announced the objectives of the studies using rhetorical questions "so, what was the aim of this study?" and providing the viewer with any necessary definitions or background information. Clear transitions were made between the different sections by, for example, announcing orally "now, let's move on to..." and also using images to frame the sections, acting as "boundary devices" (Rowley-Jolivet 2002: 30) which allow the narrator to punctuate the talk and guide the viewer through the video. A question and answer format was also used to explain certain concepts for a lay audience, "Can you tell me how a clinical trial is carried out?" while using diagrams and flowcharts to make the make the information more accessible (see figure 3 ). 
Figure 3 Visuals describing methods.
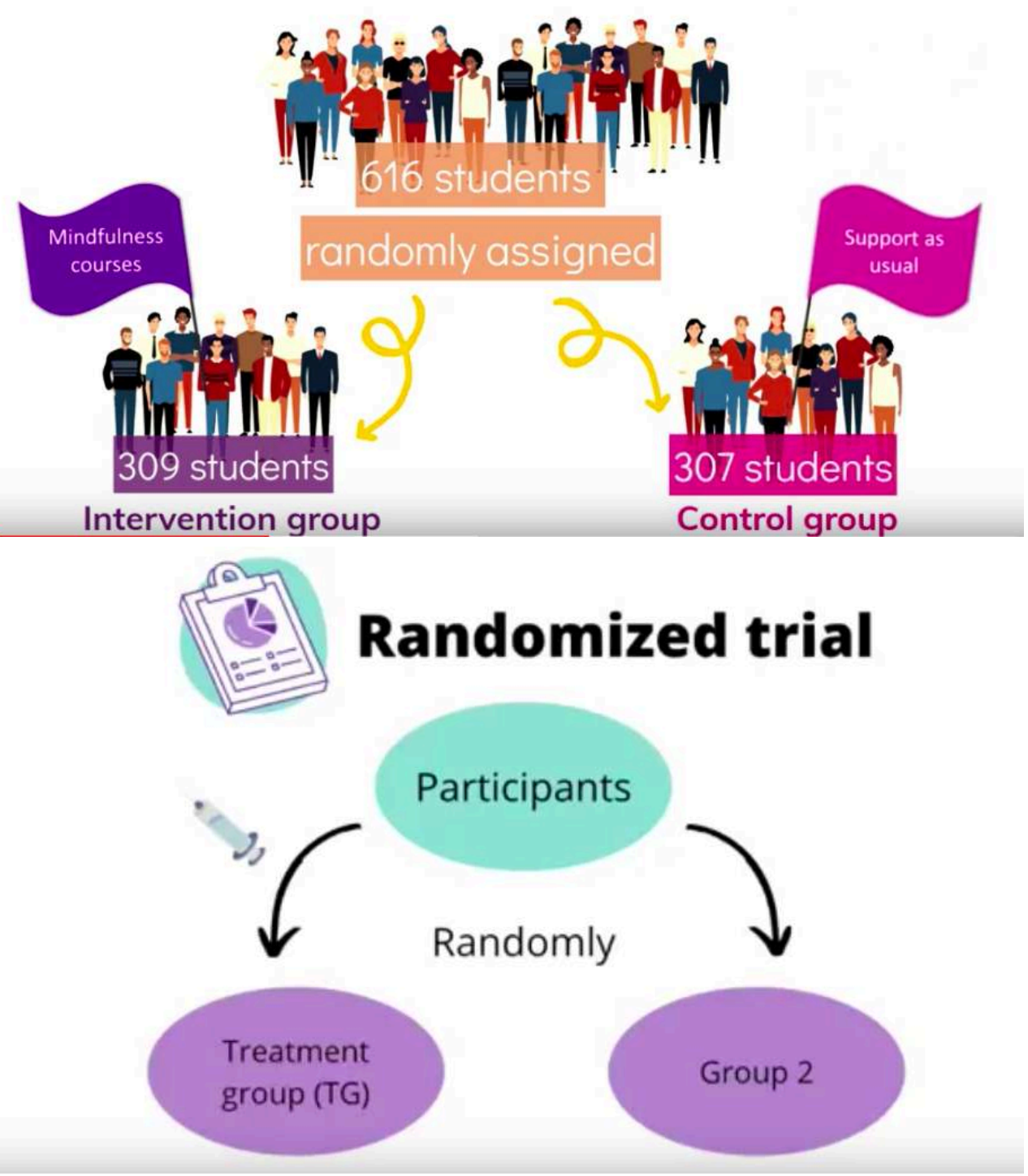

27 Visual information often served to reinforce the verbal mode, as we can see below with images which depict "preventable and curable" and "geographical correlations and temporal trends" (see figure 4). 
Figure 4. Using images to re-inforce the message.
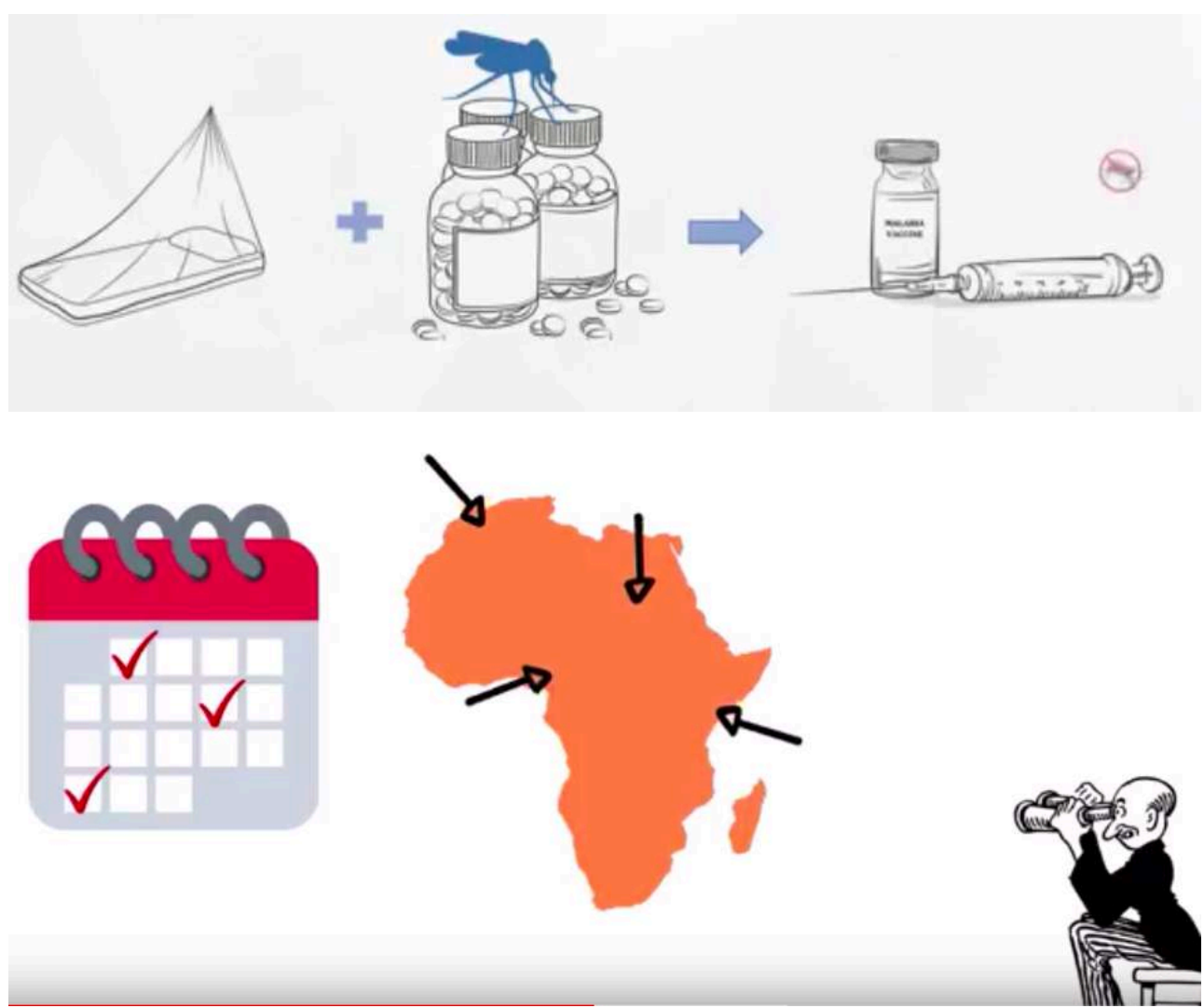
effect led to engaging productions and the students interacted successfully both with the visuals and the viewer. Students with a lower language level were able to overcome language difficulties to report effectively on the studies and the grammatical or phonological inaccuracies that did persist did not block our comprehension. The ESP and public health lecturers discussed and tended to agree upon the effectiveness of the communication in the different videos. The public health lecturer, not always aware of or paying less attention to certain phonological or grammatical inaccuracies, focused more on the content and overall effectiveness of the communication. He saw his role as assessing the students' disciplinary expertise and picked up on certain inconsistencies in the public health content that would have gone unnoticed for the ESP lecturer. In the question and answer session, he probed the students further to check their deeper 
understanding of the studies, asking them to extrapolate on methodological choices or results. Some students did find it more difficult to spontaneously justify certain aspects of the studies or clarify points either from a language perspective or a lack of disciplinary knowledge or both. This therefore gave us a balanced view of both mastery of the content and language and communication skills. In an overview of studies on "indigenous assessment criteria" in Language for specific purposes (LSP), that is to say, the views of occupational experts and non-language specialists, Whyte found that "professional experts and ordinary language users pay little attention to formal accuracy when judging communicative success" (Whyte 2019: 15). Finally, as already mentioned in this report, the aim of the course is to prepare students to work in an international context with other mostly non-native-speaker colleagues and so the main objective was to achieve effective communication. In her discussion of communicative competence in LSP, Whyte suggests that LSP teaching might focus on "linguistic and pragmatic knowledge with discourse and interactional strategies while testing might be more concerned with (...) pragmatic and content knowledge plus interactional and performance strategies". She advocates exploring a "middle ground between discrete formal linguistic criteria and broad extra-linguistic factors" (2019: 17).

\section{Assessment criteria}

The students were assessed on the following criteria: pronunciation, delivery and overall intelligibility in an ELF context, accuracy and diversity of the language used, the logical progression of ideas in a critically-minded report, their communication strategies, that is to say, the way they interacted with both the viewer and the visuals. The clarity and design of the visuals was of course also taken into account to see how they enhance communication (see appendix 1). The group comprised 19 students of heterogeneous language levels ranging from $\mathrm{A} 2$ to $\mathrm{C} 1, \mathrm{~B} 1$ being the majority.

\section{Student feedback}

Student feedback on the course was gathered by an online questionnaire completed by 14 of the 19 students (see appendix 2). Most of the students (11/14 ) thought the tasks were pertinent for their degree course and two-thirds preferred working on an animated video task compared to a "classic" academic oral presentation. Overall, they felt that the course had raised their awareness of the importance of communication in public health and the different types of communication (13/14) and that the resources and activities provided had helped them prepare for the task (12/14). From a public health perspective, they all felt they were capable of critically reporting on RCTs and interventions, describing methods, explaining results and highlighting limitations with the feedback from the public health lecturer helping them to better understand these trials and interventions (12/14). From a linguistic point of view, most students (12/14) felt that the feedback from the ESP lecturer had helped them to progress with 13/14 indicating an improved grammatical and lexical repertoire, 12/14 citing improvement of phonological aspects and structuring and development of ideas and 11/14 improvement in communicative strategies, integration of visual information. As far as research writing is concerned, almost all students (13/14) felt they now understood the differences between formal written research genres and oral discourse. They all felt 
they knew how to structure an introduction, 12/14 felt they better mastered the use of tenses in science writing and 11/14 said they knew how to refer to the literature in an intertextual way. They also felt that they were able to defend their presentations and extrapolate on their videos during the question and answer session (12/14). Their open comments concerned mostly the fact that they would have liked to have more time to prepare the video.

\section{Conclusion}

Having students produce animated videos is thus one way of familiarising students with a new, emerging genre in digital communication scientific and enabling them to enhance their communication with the multimodal affordances of the genre. The students successfully integrated the different semiotic modes appropriately. From a linguistic point of view, they adapted the discourse of the research article and their written introductions and drew on the most appropriate syntactic structures for the context to interact with their viewers, demonstrating a clear distinction between the written and spoken genres. In an ESP context, this made the information easier to follow and led to engaging videos. The course thus contributes to raising students' awareness of different modes of communication and how to adapt their discourse to the target audience. Other digital genres such as podcasts and blogs could also be used in ESP courses. As we have seen in this context, as future public health professionals, communication with their peers, governing authorities but also the general public may be of paramount importance.

The author would like to thank her colleague, Laüra Hoskins, for her valuable contribution to course design and her feedback on this report. She would also like to thank the reviewers for their insightful comments on this report.

\section{BIBLIOGRAPHY}

CARTER-THOMAS, Shirley \& Elizabeth ROWLEY-JOLIVET. 2001. Syntactic differences in oral and written scientific discourse: the role of information structure. ASp 31-33, 19-37.

CARTER-THOMAS, Shirley \& Elizabeth ROWLEY-JOLIVET. 2020. Three-minute thesis presentations: Recontextualization strategies in doctoral research. Journal of English for Academic Purposes 48, DOI: $10.1016 /$ j.jeap.2020.100897.

FELIU-MOJER Monica. 24 February 2015. Effective communication, better science. Scientific Amercican. <https://blogs.scientificamerican.com/guest-blog/effective-communication-betterscience/>. Retrieved 16 August 2021.

HAFNER, Christoph \& Lindsay MILLER. 2011. Fostering learner autonomy in English for Science: a collaborative digital video project in a technological learning environment. Language Learning \& Technology 15:3, 68-86. 
HAFNER, Christoph \& Jack PUN. 2020. Editorial: Introduction to this special issue: English for Academic and Professional Purposes in the Digital Era. RELC Journal 51:1, 3-13. DOI:

$10.1177 / 0033688220917472$

LAVE, Jean \& Etienne WENGER. 1991. Situated Learning: Legitimate Peripheral Participation. Cambridge University Press.

MARCARO, Ernesto. 2018. English Medium Instruction. Oxford University Press.

PEREZ LLANTADA, Carmen. 2016. How is the digital medium shaping research genres? Some crossdisciplinary trends. ESP Today 4:1, 22-42.

ROBIN, Bernard, R. 2008. Digital storytelling: A powerful technology tool for the 21st century classroom. Theory into Practice 47:3, 220-228. DOI: 10.1080/00405840802153916.

ROWLEY-JOLIVET, Elizabeth. 2002. Visual discourse in scientific conference papers A genre-based study English for Specific Purposes 21:1, 19-4. DOI: 10.1016/S0889-4906(00)00024-7

ROWLEY-JOLIVET, Elizabeth \& Shirley CARTER-THOMAS. 2005. Genre awareness and rhetorical appropriacy: Manipulation of information structure by NS and NNS scientists in the international conference setting. English for Specific Purposes 24:1, 41-64. DOI : 10.1016/j.esp.2003.09.003 SWALES, John. 1990. Gene Analysis: English in Academic and Research settings. Cambridge University Press.

WANG, Hui, Paul CLEARY, Julian LITTLE \& Charles AUfFRAY. 2020. Communicating in a public health crisis. The Lancet Digital Health Correspondence 2:10. DOI: 10.1016/S2589-7500(20)30197-7

WHYTE, Shona. 2019. Revisiting communicative competence in the teaching and assessment of language for specific purposes. Language Education \& Assessment 2:1, 1-19.

\section{APPENDIXES}

\section{Appendix 1: Assessment Criteria}

Pronunciation and Delivery

- Natural, comfortable

- Easy to follow for a Lingua Franca audience

- Accurate pronunciation - sounds and stress

- Varied, meaningful and engaging intonation

- Rhythm: clear, slow, pauses...

Language

- Proficient in disciplinary and general English

- Vocabulary: diverse, accurate, appropriate

- Grammar: diverse, accurate, appropriate

- Self-corrects to clarify meaning

Content \& Structure

- Develops ideas in a logical sequence

- Develops ideas fully

- Explains the research rationale 
- Critically-minded

Communication

- Uses effective communication strategies ${ }^{8}$

- Interacts well with the viewer

- Interacts well with the visuals

Visuals \& Gestures

- Clear, well-designed

- Facilitate and enhance communication

\section{Appendix 2 : Questionnaire}

Merci de choisir l'option qui vous correspond pour les questions suivantes :

Pas d'accord du tout / Plutôt pas d'accord / Plutôt d'accord / Tout à fait d'accord

- Les tâches à effectuer (rédaction d'une introduction, production d'une vidéo, séance Questions/réponses) me semblent pertinentes et bien adaptées pour des étudiants en Master de Santé Publique.

- J'aurais préféré faire une présentation orale « classique » que produire une vidéo.

- Le cours PSP 104 m'a sensibilisé à l'importance de la communication en Santé Publique et les différents types de communication.

- Les cours en ligne et en présentiel et les ressources disponibles m'ont aidé à effectuer ces tâches.

- Je me sens capable de lire de façon critique une étude sur une intervention/RCT en santé publique.

- Le retour fourni par l'enseignant de santé publique m'a aidé à mieux comprendre les interventions de Santé Publique.

- Je sais décrire la méthodologie, présenter des résultats et identifier les limites d'une étude en Santé Publique.

- Le retour fourni par l'enseignant d'anglais m'a aidé à progresser à l'écrit en anglais.

- Le retour fourni par l'enseignant d'anglais m'a aidé à progresser à l'oral en anglais.

- J'ai le sentiment d'avoir amélioré des aspects phonologiques en anglais.

- J'ai le sentiment d'avoir amélioré mon répertoire grammatical et lexical.

- J'ai le sentiment d'avoir amélioré la structure et le développement de mes idées en anglais.

- J'ai le sentiment d'avoir amélioré mes stratégies communicationnelles.

-J'ai le sentiment de savoir mieux intégrer des supports visuels pour appuyer ma communication.

-J'ai le sentiment d'avoir amélioré mon anglais plus qu'en préparant une présentation orale « classique ».

- J'ai bien compris la différence entre un registre écrit et le registre oral en communication scientifique.

- À l'écrit, j'ai appris à structurer une introduction.

- À l'écrit, j'ai appris comment faire référence à des études.

- Je comprends mieux l'utilisation des temps verbaux à l'écrit. 
-J'ai su répondre aux questions et extrapoler des idées lors de la séance questionsréponses.

- Les activités effectuées à l'Espace Langues m'ont été utiles.

Merci d'apporter tout commentaire qui vous parait pertinent pour éclairer vos réponses ci-dessus: Quelles suggestions feriez-vous pour améliorer le cours?

\section{Annexe 3: Questionnaire results}

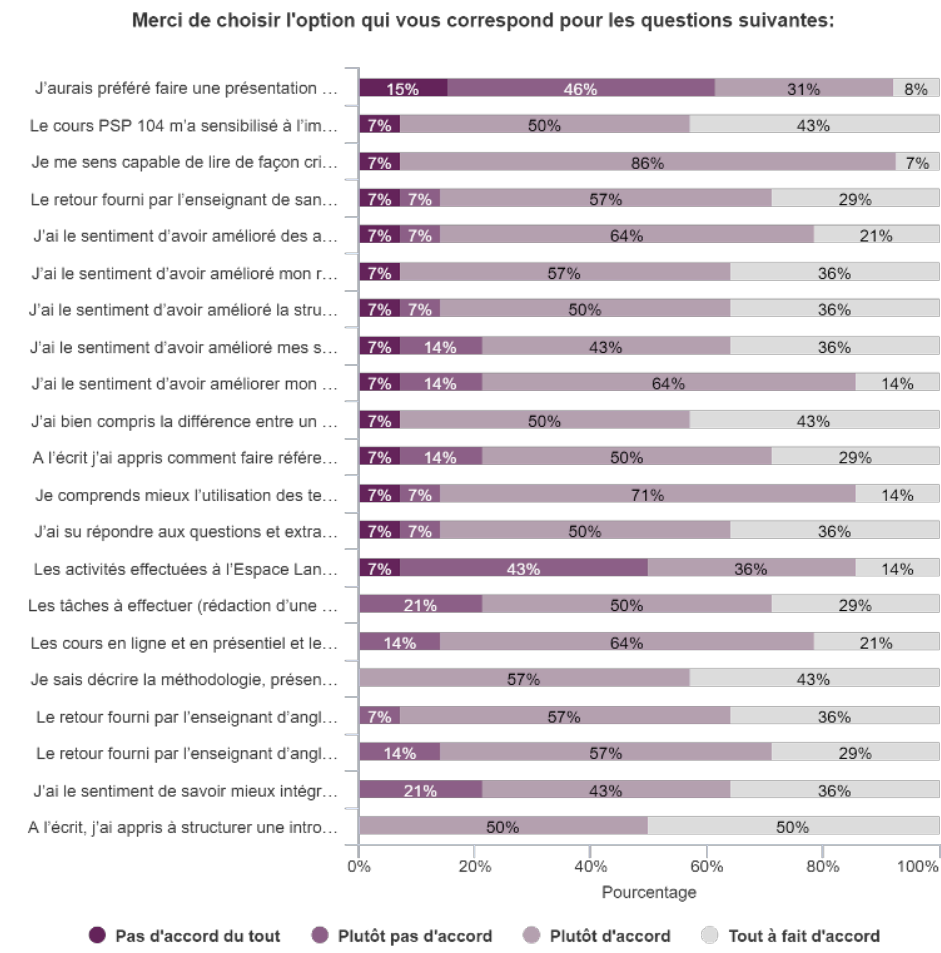

\section{NOTES}

1. <https://www.animateyour.science/post/8-ways-to-make-a-video-abstract>

2. <https://www.youtube.com/playlist?list=PLpkeJw004ccwiziI5xVauxR9xIgJW-doc>

3.

<https://www.youtube.com/watch?

$\mathrm{v}=\mathrm{A} 64$ hvopDRtw\&list=PLpkeJw004ccwiziI5xVauxR9xIgJW-doc\&index=3>.

4. <https://library.shout4he.eu/video/2>

5. <https://www.cell.com/video-guidelines>

6. See <https://www.youtube.com/watch?v=2_4HmsqKNMQ>

7. Figures represent those students who completely agreed or somewhat agreed with the statement. The results of the questionnaire are shown visually in appendix 3.

8. pre-focusing, signposting, question-raising, defining, repeating, rephrasing, summing up, recapping, anticipating, creating expectations, illustrating, exemplifying, justifying, highlighting connections, identifying with the audience, storytelling, transitioning, hedging... 
INDEX

Mots-clés: Communication scientifique, compétences orales, littératie numérique, niveau Master, résumé vidéo

Keywords: Digital literacy, Master's students, oral skills, scientific communication, video abstracts

\section{AUTHOR}

\section{SUSAN BIRCH-BECAAS}

Susan Birch-Becaas is an ESP lecturer at the University of Bordeaux where she coordinates courses for students of public health. Her research interests are the analysis of scientific discourse and its applications for written and oral scientific communication courses. She has published on recurrent errors in the writing of French researchers and the integration of $\mathrm{PhD}$ students in their discourse community. She is also interested in emerging, multimodal, digital genres in science, content and language integrated courses (CLIL) and blended learning courses.susan.becaas@u-bordeaux.fr 